\title{
STEMNINGER I KØBENHAVN UNDER KRIGEN 1864
}

\author{
BREVE FRA TROELS-LUND TIL EUG. WARMING \\ VED
}

GARL S. PETERSEN

DR. PHIL., OVERBIBLIOTEKAR VED DET KGL. BIBLIOTEK, KØBENHAVN

*

a Krigen i 1864 brød ud, var Troels-Lund 24 Aar gammel og teologisk Student. Af hans ældre Brødre deltog flere i Felttoget; den ene, Peter Lund, en ung lovende Orientalist, saaredes livsfarligt under Kampen i Kær efter Preussernes Overgang til Als og døde den 8. Juli paa Sandbjærg i Sundeved. Selv meldte Troels-Lund sig efter Dybbøls Fald som frivillig, men blev paa Grund af Omstændighederne ikke indkaldt. Egentlige Krigserindringer har han saaledes ikke kunnet efterlade sig; men hvad han hørte af andre, læste sig til i Aviser og Brochurer eller personlig oplevede, følte og tænkte, derom har han aflagt Beretning i samtidige, lange og detaljerede Breve til sin jævnaldrende Ven, Botanikeren Eugenius Warming, der siden 1863 opholdt sig i Lagoa Santa i Brasilien som Amanuensis hos hans Onkel, den berømte Naturforsker Peter Wilhelm Lund. Brevene, der er tre i Tal, findes nu paa det kgl. Bibliotek blandt Troels-Lunds efterladte Papirer.

At udgive disse Breve i deres Helhed vil der ingen Grund være til; dertil indeholder de altfor meget, der er ligesaa godt kendt andet Steds fra, ikke mindst om de militære Operationer. Derimod skal der her meddeles forskellige Uddrag, der kan vise, hvorledes Begivenheder, som senere af den modne Mand $^{1}$ erkendtes for at have været af indgribende Betydning for hans Livsgærning, afspejlede sig i Ynglingens Sind.

Det første Brev, der er skrevet i Januar i 864, fortæller om Fællesforfatningen for Kongeriget og Slesvig og dens Vedtagelse i Rigsraadet, hvilket fandt Sted under endeløs Jubel fra de overfyldte Tilhørerpladser. Derefter hedder det:

.... Søndagen [den I5de November I863] kom, den uhyggeligste Dag jeg nogensinde har oplevet. Man vidste endnu her i Byen intet om at Kongens

1 Troels-Lund: Dagligt Liv i Norden, 4. Udg. I. S. XXIX. 
Sygdom var farlig. Da kom der Telegram Kl. i I, tidsnok til at der i Kirkerne kunde bedes for hans Liv; som en Løbeild gik nu Rygtet om hans Sygdom rundt, uafbrudt gik Telegraphen med Efterretninger derovrefra; Bladene udgik hver anden Time og meldte stedse mere foruroligende Beretninger om Sygdommen. Alle strømmede til Telegraphkontoret og ventede med spændt Opmærksomhed paa hvad Telegraphen vilde bringe. Endelig Kl. 4 kom den sørgelige Efterretning at Kongen var død; hans sidste Phantasier dreiede sig om Kampen paa Dannevirke, som han troede at forsvare og opmuntrede sine Tropper til at kjæmpe tappert. En Dødsstilhed herskede her i Byen, Alle vare paa Gaden, men Skarerne gik ganske tause, man samlede sig vel i Grupper, men der lød kun sagte Hvidsken ingen lydelig Tale. Alle var dybt nedslaaede; nu netop i det Øieblik da de sidste 15 Aars Strid syntes at skulle faae en Ende, og de slesvigske Forhold ordnes, blev pludselig det næsten opfyldte Haab bortveiret og den tagen bort, der havde havt Mod til ved en rask Beslutning at ende det Hele. Dunkle Rygter gik om at Prinds Christian ikke vilde underskrive, der fortaltes han hele Eftermiddagen havde talt med sine halvtydske Venner, men Resultatet vidste man ikke. Den næste Formiddag samlede der sig en uoverskuelig Menneskemasse paa Slotspladsen forat overvære Hyldingen. Hall traadte frem paa Altanen og raabte det Sædvanlige „Kong Fredrik den syvende er død, længe [leve] Kong Christian den Niende!" Et svagt Hurra lød, Christian den 9de traadte frem, hilsede, man ventede han vilde tale, men han trak sig tilbage igjen. Da lød der et rungende Hurra for Grundloven, nok et for Ministeriet (man troede han vilde afskedige det) og saaledes blev man ved en Timestid.

Kongens Beslutning med Hensyn til Forfatningen vidste man ikke; han havde forlangt Betænkningstid det var alene det Sikre man vidste. Alt muligt gjordes nu i de følgende Dage forat bevæge ham til at underskrive, Borgerrepræsentanterne, Rigsraadet gik i Procession til ham forat bede ham derom, Deputationer fra hele Landet strømmede sammen til Kjøbenhavn forat bevæge ham, Stemningen blev mere og mere ophidset, man vidste han havde henvendt sig til Flere om at danne et nyt Ministerium, men Ingen turde paatage sig det. Hver Aften samledes vi i Studenterforeningen forat høre Dagens Begivenheder; Alle Foreninger sluttede sig sammen under een fælleds Bestyrelse forat handle i Fælledsskab, man besluttede at ingensomhelst Demonstration maatte skee naar det var blevet mørkt, og alle Medlemmer forpligtede sig til at hjælpe til Ordnens Overholdelse paa Gaderne. Man vilde nemlig mindst af Alt at det skulde kunne siges at Kongen var bleven tvungen til at underskrive, i den Henseende havde vi jo en sørgelig Erfaring fra 1848 , hvor Fredrik 7 des frie Beslutning blev opfattet 
overalt som et Resultat af Tvang. Tirsdag Aften kom en Telegraphdepesche om Oprør i Holsten, der blev almindelig Uro i Byen, vi maatte Alle anstrenge os af yderste Evne forat overtale Folk til at oppebie den næste Dag, de vilde strax ud forat opfordre Kongen til endelig at underskrive. Onsdagen den 18. underskrev Kongen om Eftermiddagen, og man saa nu med mere Ro paa Farerne udadtil. Uden Kongens Underskrift vilde nemlig Landet fra iste Januar af være ganske uden Forfatning, da den gamle var faktisk ophævet af den slesvigske Majoritet; nu var Forfatningen fastslaaet og Kongen bunden for Fremtiden til Eiderpolitiken. Fredagen den 2ode vrimlede igjen alle Gaderne af Folk der strømmede sammen paa Slotspladsen hvor Kjøbenhavns Borgere i et uhyre Optog, ledsaget af Deputationer fra alle Kjøbstæderne kom for at takke Kongen for Underskriften. Hurraraabene syntes ikke at ville faae Ende og en kort Tale som Kongen holdt (hvoraf jeg blandt Andet til min Glæde lærte, at han virkelig kan tale ordentlig Dansk) forhøiede endmere Jubelen. Rigsraadet Borgerne og Deputationer for Bønderne og andre Folk rundt i Landet, alle lovede at ville staae Kongen bie paa enhver Maade og offre alt forat forsvare Kongen og Landet mod hvad der muligt vilde skee. . . .

Under alt dette har der hersket energisk Virksomhed herhjemme forat møde Faren saa godt som muligt. Dannevirke er bleven stærkt befæstet, Armeen bragt op til omtrent 70,00o Mand, der snart alle ere samlede ved Dannevirke, Flaaden udrustes ivrigt, og der er godt Haab hos Alle. Kyndige paastaae, at Dannevirke besat med 70,000 vil kunne holde sig imod 200,000 og selv om den tages have vi de stærke Stillinger ved Dyppel og Fredericia i Ryggen. Stemningen saavel hos Tropperne som Folk i Almindelighed er den bedste, Alle have fast Tillid til at en saa retfærdig Sag som vor maa seire. Det har noget Opløftende ved sig at være Vidne til en saadan Bevægelse som den herhjemme nu, alle Partistridigheder ere ophørte, store Nationalsubskriptioner til Bedste for Soldaternes Familier ere igang, der strikkes Strømper og Undertøi i alle Huse til Soldaterne, og skjøndt den almindelige Værnepligt maa være høist trykkende for Mange, møde dog Alle med største Beredvillighed ved Fanerne. . . Sverrig og Norge ruste sig stærkt. I nogen Tid troede man at de ikke vilde tage direkte Del i Kampen, men nu synes det som det er sagt bestemt at det første Slag ved Dannevirke er Tegnet til at de komme os til Hjelp, man antager med en 25-30,00o Mand. Mange Frivillige have allerede meldt sig hernede baade fra Norge og Sverrige og tages naturligvis imod med Glæde. Det vil altsaa være første Gang at den skandinaviske Ide gjør sig gjældende i Virkelighedens Verden, jeg haaber at den fælleds Kamp frem for noget Andet vil bidrage til en inderligere Forening mellem Folkene. - 
Du seer altsaa at vort Haab om et heldigt Udfald af Krigen ikke er saa urimeligt endda, som det ved første Øiekast kunde synes; og det der fremfor Alt bestyrker os deri, er den Bevidsthed der har grebet Alle, at Kampen for Slesvig er Kampen for Danmarks Existents; erobres Slesvig vil Jylland og Øerne snart følge efter. Man er derfor beredt til at offre Alt for at bevare Slesvig og en saadan fast Beslutning hos et helt Folk maa dog vel kunne veie op mod erobrings lystne Planer, der kun ere begrundede i Frgjerrighed, selv om saa Landet hvor de opstaae var mange Gange større end vort. ... Men - kommer jeg til at tænke paa - hvorfor egentlig skrive alt dette til Dig, maaske kan de saa krigeriske Udsigter forandres, maaske kan Englands ivrige Opfordringer til Tydskland om at holde Fred blive fulgte, og hele Stillingen inden en Maaned have forandret sig aldeles, og saa har jeg uden Grund skræmmet Onkel Vilhelm og Dig ved Efterretninger som det ikke længere staaer i min Magt at meddele Slutningen paa før maaske længe efter. Dog jeg vil stole paa at de brasilianske Aviser indeholde Hovedbegivenhederne herhjemmefra, saa at hvis Situationen forandres, I da maa faae det at vide førend et nyt Brev kan naae derover; i saa Tilfælde betragt da dette Brev som et Vidnesbyrd om Stemningen herhjemme $i$ et hurtigt kommet og hurtigt svundet farefuldt Moment; men hvis ikke, da haaber jeg at disse Linier maa bidrage til hos Eder at vække det samme gode Haab om Kampens Udfald som besjæler Alle her. Det er jo dog tilsidst ikke Fjendernes Mængde det kommer an paa, men Guds Villie og han har reddet vort Fædreland ud af større Fare og Nød end den nuværende. Paa ham ville vi da haabe!...

Efterskrift.

... Ved at løbe mit Brev igjennem, seer jeg at Beskrivelsen af Christ. 9des første Regjeringsdage muligvis kunde misforstaaes som om det dog var et gjarende Oprør herhjemme Kongen maatte give efter for. Dette er kun tildels sandt. Det vilde intet Oprør være blevet, thi hele Folket var paa den ene Side, Borgere, Armee, Embedsmænd o. s. v. - Kongen derimod alene paa den anden Side. (Det sidste Halvaars Begivenheder herhjemme have nemlig gjort hele Nationen eiderdansk, og da Forfatningen var vedtaget i Rigsraadet og saagodtsom underskrevet af Fr. 7. holdt Alle paa at Christ. 9de burde overtage Underskriften som en Arv.) Kongen tøvede fordi han vidste at han ved sin Underskrift forpligtede sig til at følge Eiderpolitiken, og denne jo nødvendig maatte staae for ham og hans Omgivelser navnlig Dronningen og den tydske Familie som uheldig; - efter Underskriften da han af Begivenhederne har lært at slipper han lidt paa Slesvig for derved at vinde Holsten, mister han blot dem 
begge, har han ærligt fulgt Eiderpolitiken. Folket frygtede Opsættelsen af Underskriften, da man vidste at Noter fra Stormagterne vare underveis for at fraraade det, da det kunde ægge Tydskland. Men nu da det er skeet, indrømmes dog Rigtigheden deraf, og nu er man i Lav med Tydskland forat faae det til at være roligt. - Kongen bliver mere og mere populær, som han fra Charakterens Side vist ogsaa fortjener. Hans Valgsprog er: Fædrelandets Ære! Glædeligt er det at see at Lauenburg skjøndt omgiven af vilde Bander baade mod N. og S. har Mod til at være tro mod Danmark og aabent erklære dette.

Kjøbenhavn den 29de April i 864 .

Kjære Onkel Vilhelm og Warming!

... Efterretningen om Dannevirkes Rømning blev i Kjøbenhavn modtaget med største Forbauselse og Sorg. Den kom hertil Kl. I I næste Formiddag. Ingen vilde troe det, saa uventet kom det. Man ilede til Krigsministeriet forat faae Forklaring. Her er Krigsministeren ude af sig selv af Harme: det Hele er skeet mod hans udtrykkelige Ordre og han er forst bleven underrettet derom da det ikke længere kan ændres. Der maa da være begaaet et Forræderi. Den dybeste Fortvivlelse greb Alle. Jeg glemmer aldrig den Dag. Jeg kom fra Universitetet og anede Intet. Der var just nogle Tropper ved at drage afsted, men der lød ingen Hurraraab og glade Sange som ellers. Alle gik tause; Folk der saa dem vendte sig bort og tørrede Øinene. Det var da underligt, men nu ja ja det var maaske tilfældigt. Jeg gaaer videre ned ad Gaden. Alle som jeg møder have den dybeste Smerte malet i deres Aasyn. Blege med knyttede Hænder og Taarer i Øinene gaae de stille, Ingen taler til en Anden, Ingen seer til en Anden. Jeg ilede ned i Krigsministeriet og fik den overvældende Efterretning at vide. Man ventede og ventede paa Forklaring, men der kom ingen. Herhjemme sad vi ved Middagsbordet, Ingen kunde nyde noget. Vi drøftede de forskjellige mulige Forklaringer, men ingen var fyldestgjørende. Der maatte være Forræderi med i Spillet. Nu seer man det Gud ske Lov i et andet Lys, men tænk Eder hvorledes Stemningen dengang maatte være. Vor Hær var kun lille, intet mod den fjendtlige Overmagt, og nu var den ved lumske Forrædere i dens egen Midte lokket bort fra den eneste Stilling, hvor dens Lidenhed ikke var afgjørende. Landet laa nu aabent. Lige til Skagen kunde Fjenden uhindret trænge. - Aftenen kom, men endnu ingen Forklaring. Lad mig slippe for at omtale den Nats bedrøvelige Optrin. Folket var fortvivlet, Fortvivlelsen vilde have Luft, der var intet at lade den gaae ud over, man greb da den første den bedste Anledning. Politiet bad Masserne spredes, der blev Klammeri, den fælleds Nationalsorg 
gjorde begge Parter uimodtagelige for Fornuftgrunde og en Kamp begyndte. Dog lad mig forbigaae det Hele, det staaer nu for Tanken som en hæslig svunden Drøm. Var end Offrene fra hin Nats Strid i Antal kun faa, hvert eneste var beklageligt, dobbelt fordi det var saa unyttigt. Endelig lidt efter lidt kom der da mere og mere op om Sagen og i Løbet af den næste Dag begyndte Taagerne at spredes.

De Meza havde handlet ganske paa egen Haand; forat ikke Efterretningen skulde komme i Fjendens Hænder havde han ladet være med at underrette Krigsministeren om det før bagefter og altsaa taget hele Ansvaret paa sig. Dette var maaske rigtigt; men hvad man med Grund har anket over er Maaden hvorpaa Tilbagetoget skete, navnlig den liden Omhyggelighed Meza viste for Soldaterne, selv kjørte han foran i en lukket Wienervogn til Flensborg og lod Armeen skjøtte sig selv. Han blev strax hentet til Kjøbenhavn, stillet for en Krigsret og forflyttet fra sin Post. Hele Spørgsmaalet om Rigtigheden af Dannevirkes Rømning staaer endnu herhjemme som uafgjort, hvad der mest taler derimod er den Omstændighed at Fjenden neppe vilde kunnet holde ud i mange Dage at ligge under aaben Himmel i saa stærk en Frost uden at have Tag over Hovedet om Natten og uden engang at kunne tænde et Baal; thi der er saa godt som ingen Byer eller Huse lige syd for Dannevirke; vore der vare vante til Klimaet kunde bedre finde sig deri. Men der hører saa mange Momenter til at kunne have en begrundet Mening om det Hele at jeg med de Oplysninger der endnu foreligger troer det umuligt at fælde en retfærdig Dom. ...

... Armeen staaer nu paa Als og befæster sig stærkt der. Fredericia har man belært af Erfaringen fra Dybbøl om Fjendens overlegne Skyts, frivilligt rømmet i disse Dage; den kunde nemlig ikke holdes, det var kun et Tidsspørgsmaal, hvorlænge den kunde forsvare sig, og naar den toges vilde hele Besætningen blive taget, hvilket vi jo ikke have Raad til.

Men, spørge I, saa er vel Danmark nu snart udtømt, og vil om kort Tid komme til at afgive det sørgelige Billed af et nyt Polen, thi der er ingen Tvivl om at Preussen forlængst har glemt hvad den egentlig begyndte Krigen for, og kjæmper $\mathrm{nu}$ for blot at rive saa meget til sig som muligt og narre baade Tydskland og Schleswigholsteinnismens Phantaster ved selv at beholde alt det Erobrede. Det kan undertiden i et mørkt Øieblik stille sig saaledes men for en rolig Betragtning viser det sig anderledes. Vel har Krigen været den blodigste vi vist nogensinde have ført. I 3 Maaneder have vi vist mistet en 20,00o Mand ved Sygdom, Faldne Saarede og Fangne, hele Halvøen er besat og i aaben Mark kunne vi ikke møde Fjenden; men, og det er det afgjørende, vi ere Herrer paa Søen, alle 
preussiske Østersøhavne blokeres, Handelen ligger ganske hen og skal dette vare ved til Høsten kommer vil Landet der jo lever af Kornudførsel ganske ruineres. Derfor: Preussen maa have Fred og snarest muligt. Vi kunne forhaabentlig forhindre ved Skibene at Fjenden kommer over til Øerne, og i saa Tilfælde kan vi holde ud en god Stund endnu; Armeen er stor nok til at kunne forurolige Fjenden føleligt ved hyppige Landgange rundt om paa Halvøens Kyster. Østerrig er led og kjed af Krigen og vil gjerne slutte Fred paa status som før Kong Fredrik d. 7des Død. England er bleven haanet til det Yderste af Preussen for dets holdningsløse Politik, og det engelske Folk har gjentagne Gange heftigere og heftigere fordret af Regjeringen at komme os til Hjelp. Rusland vil paa ingen Maade see det danske Monarchies Integritet ophævet ऽ: et uafhængigt el. preussisk Schleswigholstein. Preussen er bleven aldeles overmodig efter Seiren ved Dybbøl og fornærmer til Høire og Venstre, tillige bringes det efterhaanden i en vanskelig Stilling ligeoverfor alle dem, hvem den har lovet at bevare Danmarks Integritet ว: blot at gjøre Exekution. Kort sagt: den politiske Himmel er langt fra saa formørket for os som man skulde troe. - Og herhjemme er Stemningen fortrinlig. Aldrig har jeg været saa stolt af at være Dansk som netop i disse Tider. Alle ere ved godt Mod, de største Offere bæres med Taalmodighed; paa Efterretningen om Dannevirke nær ere alle Efterretninger, gode og onde, og de sidste har der jo været flest af, blevne modtagne med mandig Ro og tillidsfuld Fortrøstning til Gud og vor retfærdige Sag. I skulde seet, hvilke uhyre Summer der er bleven indsamlet til de Saarede, til Beboerne af Sønderborg, til de Faldnes Efterladte, det er i I 0o,00o vis, Enhver selv den fattigste vil give med. Overalt $i$ alle Forhold seer man Beviser paa hvorledes Enhver glemmer sig selv for at hjelpe det fælleds Fædreland. Armeen er bestandig ved godt Mod, den har kjæmpet saa selv vore Fjender have maattet beundre den. Og den hele Stemning herhjemme næres stadig ved Yttringer af Sympathi fra hele Europa: Italien, Schweitz, England, Holland have sendt Adresser til os og gjort store Indsamlinger til vore Saarede. En Mængde Svenske og Normænd (de ere nu saa mange at de skulle danne et eget Regiment) have meldt sig frivilligt og kjæmpet med. Selv Polakker og Grækere have meldt sig (dog troer jeg forresten Regjeringen herhjemme har afslaaet alle andre Frivillige end Nordmænd og Svenskere, heldigvis melder der sig især mange Officerer som vi have megen Brug for). Det er hele Nationens sikkre Overbevisning, at naar vi blot holde ud faae vi nok en god Fred. ... 
Kjøbenhavn den 6te December I864.

Kjære Onkel Vilhelm og Warming!

Det er med underligt blandede Følelser jeg begynder paa dette Brev. Siden vi sidst taltes ved, har baade vort Fædreland og vor snevrere Kreds i Hjemmet lidt store Tab, Tab som Tanken har saa ondt ved at gjøre sig fortrolig med, og som dog hvert Øieblik kun altfor tydeligt bekræfter. Jeg har med Villie undladt at skrive Eder til i længere Tid for ikke uden Nytte at drage Eder ind i al den forvirrede Blanding af Sorg og Nedtrykthed som de sørgelige Begivenheder nødvendigt have medført; thi naar Alt kommer til Alt er det Hele dog lettere at bære nærved end paa Afstand. Først nu, da Stemningerne mere have udgjæret og man med roligere Blik kan maale Størrelsen af Tabet men ogsaa af Haabet og Alt det vi endnu have tilbage, skriver jeg Eder til og lader naturligvis Tanken dvæle ved det Meget, der er skeet i den mellem liggende Tid. Hovedtrækkene kjende I vel: Først det lysende Punkt, den glimrende Træfning ved Helgoland, saa den lange Vaabenhvile med dens Haab om fredelig Løsning eller engelsk Hjælp, saa det tunge frygtelige Slag Tabet af Als med dets i4 Timers Blodbad og endelig den sørgelige nødtvungne Fred. Jeg vil ikke indlade mig paa at bedømme Begivenhederne, f. Ex. det Fornuftige eller Ufornuftige i at optage Krigen paany og ikke hellere modtage de stillede Betingelser, eller hvorvidt det var rigtigt af det nye Ministerium, der kom efter Als's Erobring, at gaae ind paa en saa ugunstig Fred og ikke hellere, saaledes som netop det Ministerium formaaede, samle alle Partier til en sidste fortvivlet Kamp, om alt Dette maa Historien fælde Dom, vi staae for nær til at have et uhildet Blik. Jeg vil indskrænke mig til at fortælle Eder om det Indtryk Begivenhederne have udøvet paa os herhjemme og saa vidt muligt beskrive Eder Tilstanden her i den forløbne Tid. I kan troe det var glade Dage, da Efterretningen om Slaget ved Helgoland kom hertil. Først vilde Ingen ret fæste Lid til den; vante til sørgelige Budskab nærede man uvilkaarlig Mistro til et glædeligt. Men det bekræftede sig. Det var den første Gang der var kjæmpet med omtrent lige Styrke og vore havde med ringe Tab vundet en fuldstændig Seir. Det var et stolt Syn et Par Dage efter at see Skibene Iste Pintsedag i det deiligste Veir komme glidende majestætisk ind forbi Trekroner. Takkelagen var i en Hast repareret og alle Hullerne i Skrogene vare foreløbig skjulte med Propper og overtrukne med Lærredsplastre, saa Skibene saa ganske uskadte ud. Peter, Ferdinand (en I6 Aars Søn af Onkel Mourits i Kallundborg i Huset hos os) og jeg havde fra Morgenstunden af ligget og roet omkring $i$ en Baad for strax at tage imod dem; Sundet var som overfyldt af lig- 
nende Baade, tilsidst roede ogsaa Kongen dem imøde og gik under uendelig Jubel om Bord. Onkel Sigvardt havde ført Corvetten Heimdal og udmærket sig. Han var uskadt. Vi var de første der fik hilst paa ham. Om det saa var Fader, hvis Vei aldrig ellers gaaer til Toldboden, var han med Jette gaaet derud og var med i den jublende Stimmel da Officererne kom i Land. Det var glade Dage, men de varede kun kort. ...

... De senere Begivenheder kjende I vel altfor vel. Den krænkende Fred med Tabet ikke blot af Holsten og Lauenborg, men af det gamle danske Kronland, Slesvig, vor Nationalitets og Sprogs Formur mod Syden. Krigen, der oprindelig begyndte under Paaskud af at værne om formentlig krænkede nationale Rettigheder er endt med at træde de samme Rettigheder aldeles under Fødder ved at lade 200,000 dansktalende Slesvigere komme under fjendtligt Aag, berøve dem deres Sprog og med Vold indføre tydsk Regimente tydsk Sprog. Det sidste Haab er at Nordslesvigerne ville trods al udvortes Tryk og Overlast vide at bevare den gamle Hengivenhed for Dansk og Danmark og udvise deres vante Seighed og passive Modstand mod al fremmed Voldsdaad. Skjøndt kun saa kort Tid er gaaet er allerede selv de ivrigste Wühlere i Sydslesvig og Holsten blevne kjede af preussisk Regimente og længes tilbage til den gamle Tilstand under den milde - desværre altfor milde - danske Regjering. Kunne de ikke blive selvstændige ville de være danske igjen, paa ingen Maade preussiske. Der er vist forresten Ingen der spørger dem om deres Mening nu. Preussisk Jernscepter vil vel lære dem at tie og kue enhver Frihedsbevægelse. Og man kan ikke have Medlidenhed med dem, deres barnagtige Lyst til Forandring og affekterte Veeklager over Undertrykkelse har kostet Tusinder af Mennesker Livet, Strømme af Blod ere flydte forat hævne Uretter der aldrig ere blevne begaaede og nu, men først forsilde, opdage de at de have ladt sig forlede af tydske Agitatorer til at klage over deres Tilstand og at deres lykkelige Tid er forbi; Frihed, Selvregjering, smaa Skatter, materiel Velvære ved Danmark som Opland for Produkter og Fabrikata - Alt dette miste de ved Tilslutning til Tydskland og faa Intet isteden. Hvorledes forresten det Hele vil ende kan Ingen sige endnu. Preussen, Østerrig, Augustenborgerne, Oldenborg gjøre alle Fordring paa Hertugdømmerne. Herhjemme drømme mange endnu om Muligheden af en Personalunion med Danmark, naar de Andre ikke kunne blive enige. Det vilde vist blive en ulykkelig Løsning, saavidt jeg kan see. Preussen vilde af Lyst til Krigshavne snart igjen fornye Krigen og vi ville ligge i evige Feider. Den ønskeligste Løsning efter min Mening er en Deling af Slesvig efter Nationaliteterne, men det have vi jo desværre kun meget ringe Udsigt til. Nordslesvigerne ere tro til 
det sidste, endnu forleden Dag da Kongen var i Kolding mødte over 5,00o Slesvigere, trods alle Forsøg fra den fjendtlige Regjering paa at forhindre det, under almindelig Jubel i Kolding forat hilse paa deres fordums Konge og udtale Haabet om snart atter at forenes med Danmark. Hvorledes alt Dette skal ende maa Gud vide.

Herhjemme seer det sørgeligt ud. Krigen har medført tunge Offre for de Fleste. Dens ulykkelige Udfald har ikke bidraget til at læge de derved lidte Saar. Byen er fuld af fordrevne slesvigske Embedsmænd med ringe Pensioner. Armeen Flaaden Ministerierne indskrænkes i Forhold til Rigets formindskede Størrelse og en Mængde Familier komme derved i meget trange Kaar. For enhver Studerende er der kun meget ringe Udsigter da der jo for lang Tid er nok af Aspiranter til ledige Embeder i alle de afskedigede Embedsmænd. Dog alt dette er jo Onder som Tiden vil læge. Ogsaa gode Følger har den sørgelige Tid havt, som man ikke maa oversee: En forøget Kjærlighed til det haardt prøvede Fædreland, en Følelse af at kun ved Anstrængelse af alle aandelige Kræfter kan vi redde vort Sprog og Fædreland fra Undergang, en Lyst til Uafhængighed af tydsk Videnskab og Kultur, naar den ikke vil tillade selvstændig Tilegnelse - saadanne Følelser samtidig med at Folket staaer i fuld usvækket Aandskraft kunne kun love gode Frugter. Det er altsammen Spirer der skjød frem og fik Liv I 848 og som den senere Tid, ogsaa dens smertelige Erfaringer, har bidraget til at udvikle. Paa de fleste videnskabelige Gebeter hvor vi tidligere have staaet tilbage er der i senere Tid fremkomne Værker, der ere en Pryd for vor Literatur, saaledes navnlig paa det historiske, philosophiske og theologiske Gebet. Et Værk jeg navnlig vil nævne er et fortrinligt historisk af Allen: Norden i Unionstiden, hvoraf netop de første Dele ere udkomne nu. Et andet glædeligt Tegn er den Sammenslutning af Partierne der i den senere Tid har fundet Sted, ikke paa det politiske Gebet, thi der staae de skarpt nok overfor hinanden, men paa det religiøse, videnskabelige og kunstneriske Omraade. En velgjørende Følelse af at enhver selvstændig Stræben er berettiget og tillige gavnlig da den forøger vort aandelige Rige - er et heldigt Kjendemærke paa Nutiden herhjemme. ...

... Jeg selv har dygtig travlt med Examenslæsning, hvori jeg blev afbrudt af Krigsbegivenhederne, men som man nu med dobbelt Ro netop ved de lidet tillokkende ydre Forhold kan give sig hen til. Jeg haaber at kunne tage Embedsexamen (i Theologi) om et Aar og vil da fortsætte mit tidligere paabegyndte Studium af den græske Philosophi. Geistlig Virksomhed føler jeg hverken Kald eller Lyst til, men desmere til mit Yndlingsstudium Philosophi, det theologiske Studium betragter jeg som en passende Omvei dertil, det er det Embedsstudium 
der tilbyder sig som det nærmeste. Det philosophiske Studium hører jo unægtelig til de brødløse, men det har det tilfælleds med de fleste videnskabelige, og man finder vel nok paa en eller anden Maade en liden afsides Krog, hvor man kan have Lov til at sidde og studere i Ro. Det er mit Ræsonnement, som Fader vistnok leer ad, naar han i Spøg foreholder mig at alle Philosopher enten døe af Sult eller tilsidst lade Philosophien fare og see at faae en rig Enke. - Men nu er Papiret nok paa Heldingen, lev da vel og modtag de kjærligste Hilsener fra os alle især fra Eders hengivne

Troels Lund.

Hvis mine Breve for Fremtiden blive kortere saa er Examens Læsningen Skyld deri. Det lakker nu ad Jul, derfor har man Lov til at puste lidt og skrive Breve. 